\title{
Determination of Curie Depth Isotherm and Geothermal Studies over Parts of Nasarawa and Environs, North Central Nigeria
}

\author{
Rowland Akuzigi Ayuba ${ }^{*}$, Ahmed Nur \\ Department of Geology, Moddibbo Adama University of Technology Yola, Yola, Nigeria \\ Email address: \\ akuzigi@yahoo.com (R. A. Ayuba), anur07@gmail.com (A. Nur) \\ ${ }^{*}$ Corresponding author
}

\section{To cite this article:}

Rowland Akuzigi Ayuba, Ahmed Nur. Determination of Curie Depth Isotherm and Geothermal Studies over Parts of Nasarawa and Environs, North Central Nigeria. International Journal of Energy and Environmental Science. Vol. 3, No. 4, 2018, pp. 69-81.

doi: $10.11648 /$ j.ijees.20180304.11

Received: April 23, 2018; Accepted: May 17, 2018; Published: September 25, 2018

\begin{abstract}
The high resolution aeromagnetic data was analyzed to estimate depths to the bottom of magnetic sources as proxy information about the thermal conditions within the crust in Nasarawa area. This area is particularly important for geothermal exploration because of its high heat flow and geothermal gradients. The result of this investigation revealed that Curie point depth vary between $18 \mathrm{~km}$ and $23 \mathrm{~km}$ with deeper Isotherm at the northwestern part and shallow Isotherm at the south eastern part, this means that the Curie Isotherm surface around Awe Dorowa and Akiri may likely coincide with the Moho, these variations of curie depth isotherm could be related to the different tectonic activities, which involve astenospheric updoming, crustal thinning and stretching, emplacement of igneous bodies and block faulting in the Benue Trough. The calculated heat flow varies between $63 \mathrm{mWm}^{-2}-80 \mathrm{mWm}^{-2}$ and geothermal gradient varies between $25^{\circ} \mathrm{C} / \mathrm{km}-32^{\circ} \mathrm{C} / \mathrm{km}$. The south eastern part is characterized by high heat flow $\left(80 \mathrm{~mW} / \mathrm{m}^{2}\right)$, and shallow Curie depth $(18 \mathrm{~km})$, due to the geothermic nature of the area, the heat due to magmatic activities as well as heat from thinning of the crust is responsible for raising the temperature in these areas. The north western portion of the studied area has lower heat flow $\left(63 \mathrm{~mW} / \mathrm{m}^{2}\right)$ and deeper Curie depth $(23 \mathrm{~km})$ due to Isostacy. Variations in the Curie Depth compare reasonably well with the heat flow and with the Geothermal Gradient, this study also revealed that the south eastern part of the study area has potentials for geothermal energy.
\end{abstract}

Keywords: High Resolution Aeromagnetic Data, Curie Point, Geothermal Energy, Akiri

\section{Introduction}

The search for non-fossil energy sources such as geothermal energy is generally on the increase in the world today, because it is renewable, valuable, simple and a clean source of energy that can help mankind in different ways, though it is undergoing development in Nigeria and from existing literatures on geophysical work in the area there are very few or no records of crustal temperatures and geological structures that serve as geothermal reservoir with the High Resolution Aeromagnetic data. One of the methods of examining thermal structure of the crust is the estimation of the Curie Point Depth (CPD), using aeromagnetic data [9]. Various studies have shown correlations between Curie temperature depths and average crustal temperatures, leading to viable conclusions regarding lithospheric thermal conditions in some regions around the world [26]. Evaluation of geothermal potential is done by applying the spectral analysis method to the aeromagnetic data. The model has proven successful in estimating average depths to the tops of magnetized bodies [32].

The study area is located between longitudes $8^{\circ} 00^{\circ} \mathrm{E}$ and $10^{\circ} 00^{\circ} \mathrm{E}$ and latitudes $7^{\circ} 30^{\circ} \mathrm{N}$ and $9^{\circ} 30^{\circ} \mathrm{N}$ in north central Nigeria (Figure 1). The area is part of the Basement complex of North-central Nigeria and the Cretaceous sediment of the Middle Benue Trough, it covers an approximate area of $48,400 \mathrm{~km}^{2}$, and covers farmlands, villages, towns, game reserves, natural reserves etc. Topographically, the study area is hilly at the northern fringes and drained mainly by river Benue and its tributaries in the southern part, it is 
characterized by moderate relief with high granitic hills generally extending several kilometers, having the NE - SW direction and forms several peaks of relatively higher elevation than the surrounding rocks. Despite the hilly nature of some part of the study area, there are still good road networks, foot-paths and tracks in the area. Major roads found in this area provide access road to the southeastern part of Nigeria and some other communities in the study area such as Akwanga, Nasarawa-Eggon, Lafia, Keana, Awe, Doma, Shendam, Pankshin to mention few. There are other minor roads that provide access to smaller settlements, farms, rivers and streams.

\section{Geology of the Study Area}

The geology of the Middle Benue Trough (MBT) has been described in some details by [20]. The oldest rocks belong to the Asu River Group: a mixture of lava-flows, dykes and sills representing the first middle Albian episode into the Benue Trough. The Awe Formation marks the beginning of the regressive phase of the Albian Sea, it consists of transitional beds of flaggy, whitish, medium to coarse-grained sandstones interbedded with carbonaceous shales from which brine springs issue continuously $[10,20]$. The Keana Formation resulted from the Cenomanian regression, which deposited fluviodeltaic sediments in the Lafia-Awe area. This formation consists mainly of crossbedded, coarse-grained feldspathic sandstones. The sandstone is generally poorly sorted and occasionally contains conglomerates and bands of shales and limestones towards the top. Ezeaku, Agwu and Lafia Formations are also present and these represent the Turonian to Early Maastrichtian sediments in the MBT. The Ezeaku Formation comprises essentially of calcereous shale, micaceous fine to medium-grained friable sandstones, with occasional beds of limestone. The Conician Agwu Formation consists mainly of black shale, sandstones and local coal seams. The Maastrichtian Lafia Formation is the youngest formation reported in the Middle Benue Trough and consists of coarse-grain ferruginous sandstones, red loose sand, flaggy mudstones and clays [20].The basement complex are also present in the study area (Figure 1) These basement complex rocks are of Precambrian age and consist mainly of granulitic gneisses, migmatite and older granite. The Jurassic (145-210Ma) Younger granites in the study area are high level, anorogenic granites; they mainly consist of microgranites and biotite granites, porphyries and rhyolites which outcrop at the northern fringes. Tertiary- Recent volcanic rocks which consist of the Basalts, Trachyte, Rhyolite, and newer basalts of Sura volcanic line also occur in the area.

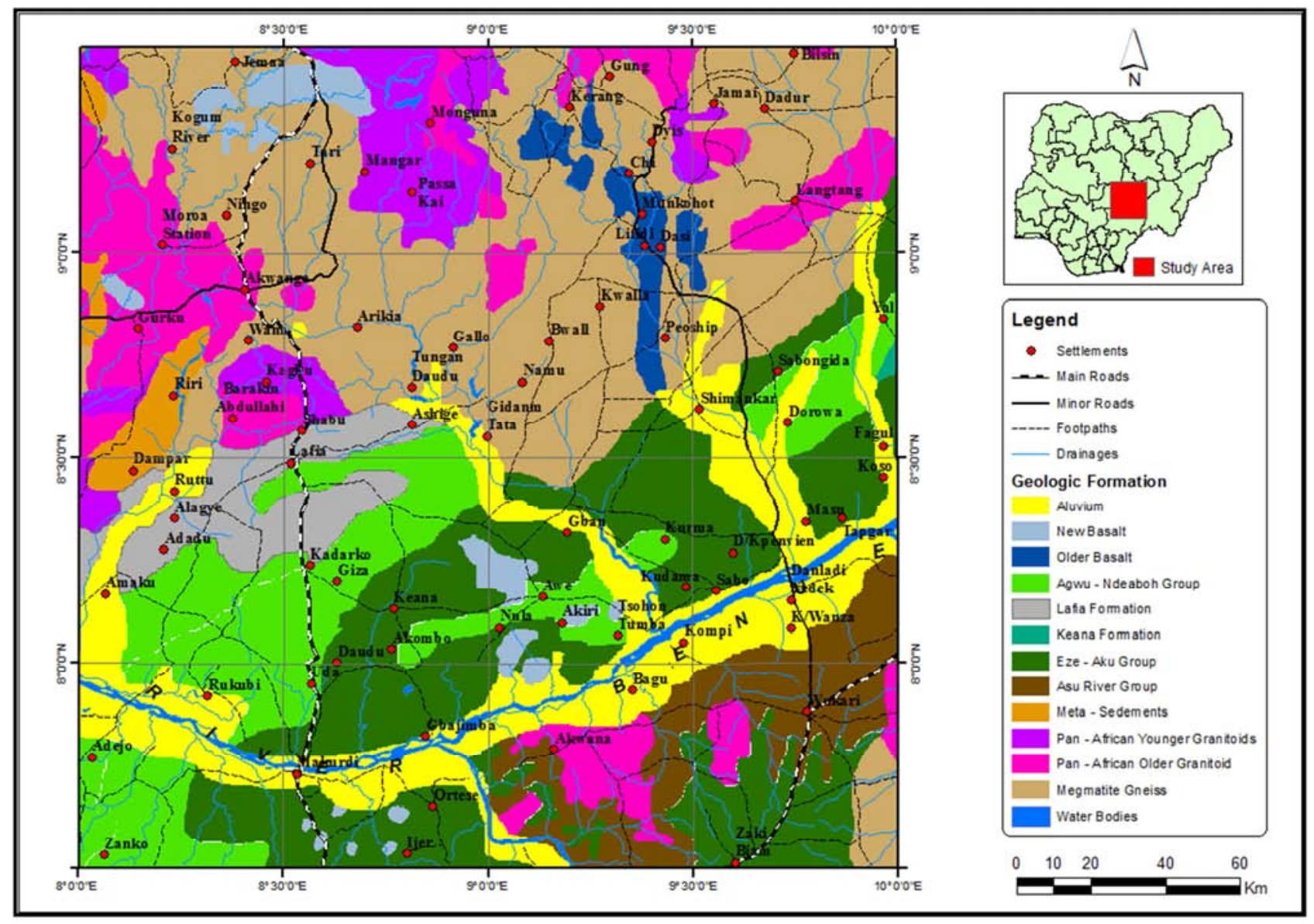

Figure 1. Geological map of the study area (Adapted from [14]). 


\section{Materials and Method}

The high resolution aeromagnetic data (HRAM) used for this work was obtained from the Nigerian Geological survey agency Abuja, which had acquire digital data for the entire country between 2005 and 2009 [15]. The airborne survey was carried out for the Nigerian Geological Survey Agency by Fugro airways services, the surveys was flown at $500 \mathrm{~m}$ line spacing and at an average flight elevation of $80 \mathrm{~m}$ along NW - SE direction, and published in form of grid (digital form) on $30^{\prime}$ by $30^{\prime}$ sheets. The IGRF has been removed from the data. Sixteen sheets were assembled for this work with each square block representing a map in the scale of $1: 100,000$. Each square block is about $55 \times 55 \mathrm{~km}^{2}$ covering an area of $3,025 \mathrm{~km}^{2}$ hence the total area studied is about $48,400 \mathrm{~km}^{2}$, the digital data was acquired as merged unified block from which the sixteen sheets are windowed after a polygon had been created by means of a computer program Oasis montage version 7.5.

To remove the regional magnetic field, which is the anomalies associated with low frequency components, a plane surface was fitted into the digital data by polynomial fitting least square analysis. In this method, the matching of regional by a polynomial surface of low order exposed the residual features as a random error, the treatment is based on statistical theory. The observed data are used to compute, usually by least squares, the mathematically describable surface giving the closest fit to the magnetic field that can be obtained within a specified degree of detail $[8,12,28]$. This surface is considered to be the regional and the residual is the difference between the magnetic field value as actually mapped and the regional field value, thus determined [34].

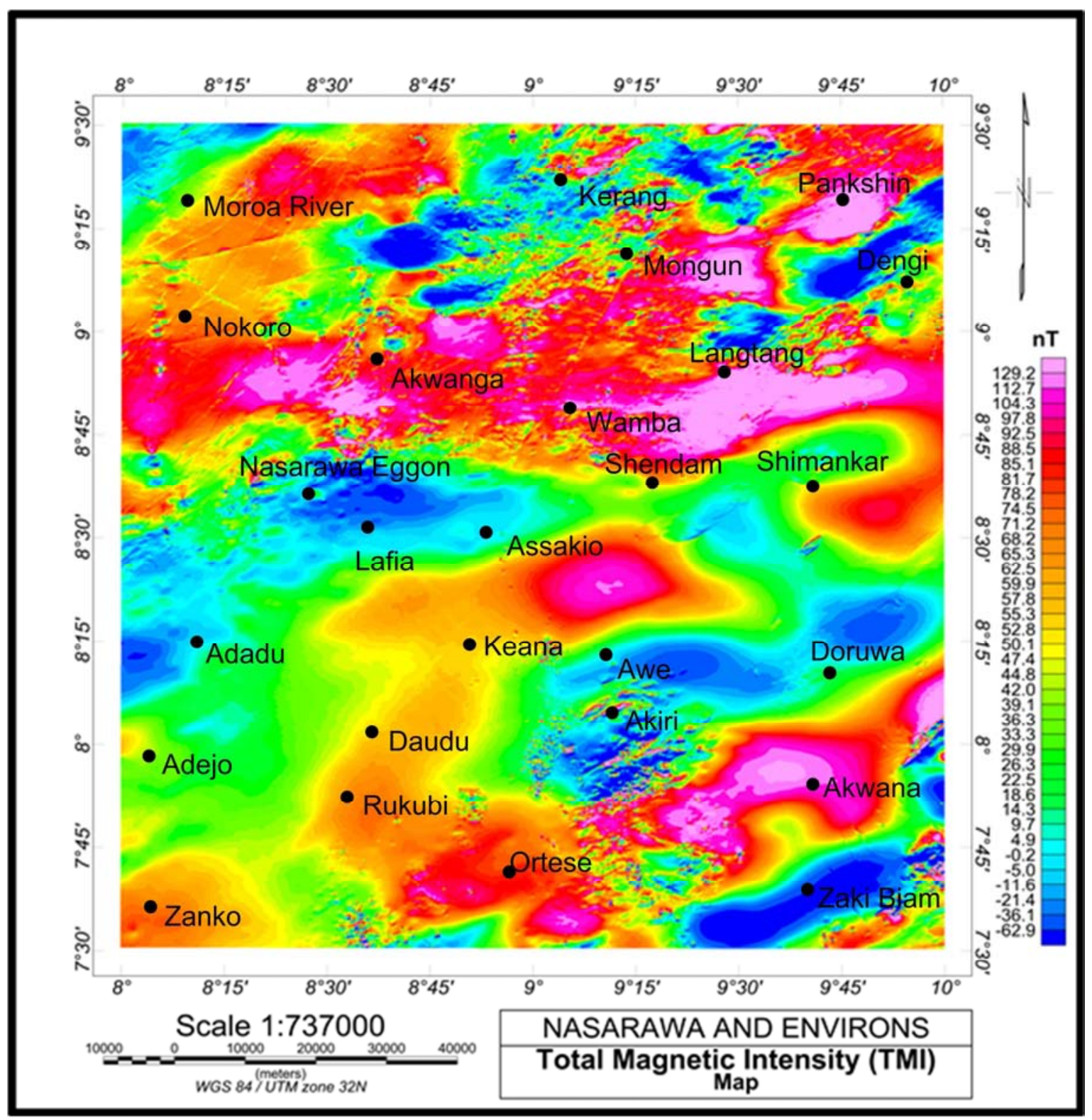

Figure 2. Total Magnetic Intensity Grid Map of the Study Area. 


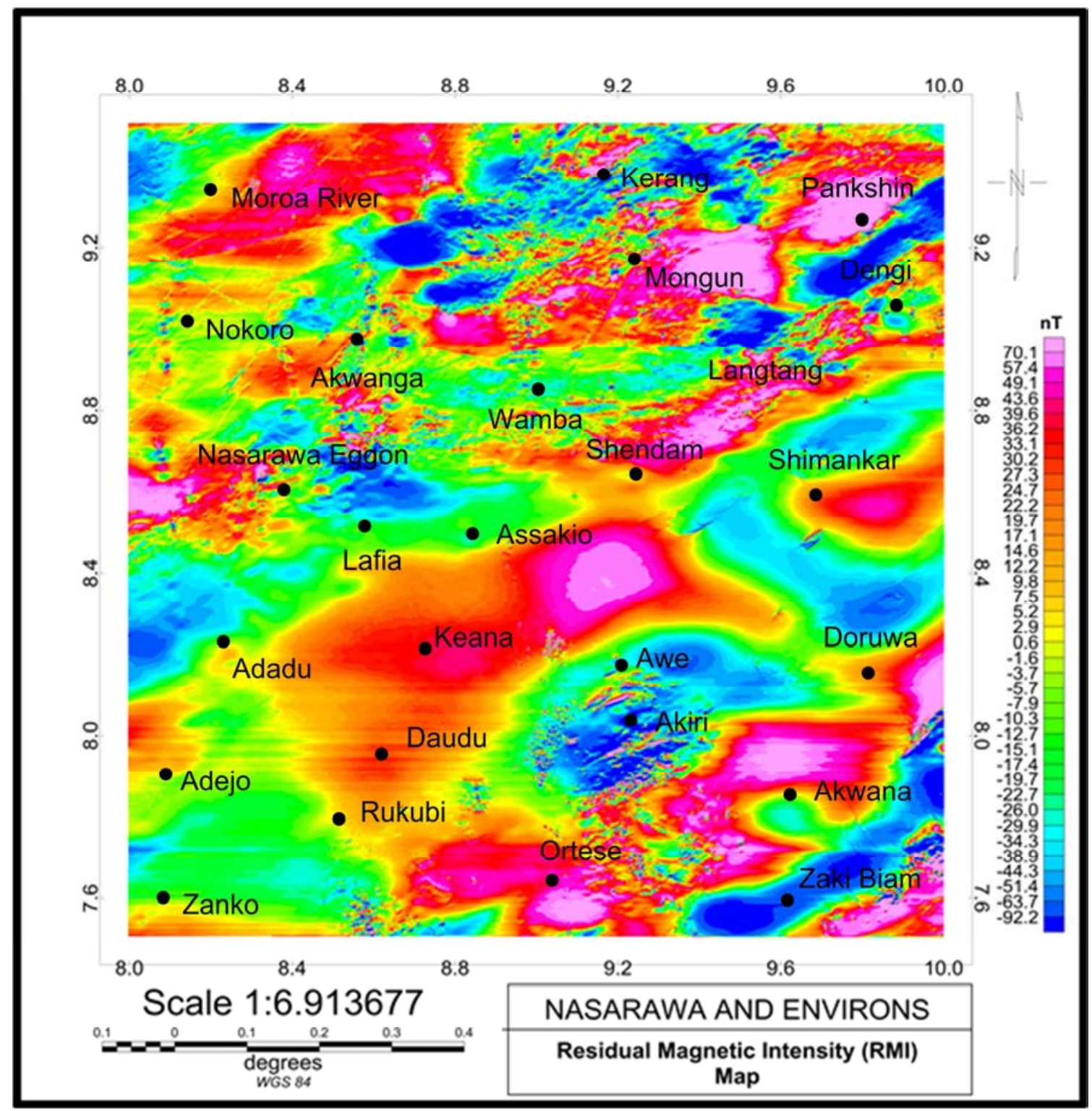

Figure 3. Residual Magnetic Intensity Grid Map of the Study Area.

\section{Curie Point Determination}

The idea of using magnetic method to determine the Curie depth is based on the theory proposed by [2] and developed by $[5,30,31]$. They all used the analysis of the power spectrum of the magnetic data to estimate the Curie depth. In this technique, the Curie temperature isotherm corresponds to the temperature at which magnetic minerals lose their ferromagnetism (approximately $580^{\circ} \mathrm{C}$ ). Magnetic minerals warmer than their Curie temperature are paramagnetic and are essentially non-magnetic. Thus, the Curie Depth Isotherm corresponds to the basal surface of magnetic crust and can be calculated from the power spectrum of the magnetic anomalies $[4,7,18,27]$.

The methods for estimating the depth extent of magnetic sources are classified into two; those that examine the shape of isolated anomalies [1] and those that examine the patterns of the anomalies [30]. However, both methods provide the relationship between the spectrum of the magnetic anomalies and the depth to magnetic sources by transforming the spatial data into frequency domain. The method used here is similar to that of $[23,24,31]$. The top bound and the centroid of a magnetic source, $Z_{t}$ and $Z_{0}$, respectively are calculated from the power spectrum of magnetic anomalies and are used to estimate the basal depth of a magnetic source $Z_{b}$.

The first step, is the estimation of depth to the centroid $\left(Z_{0}\right)$ of the magnetic source from the slope of the longest wavelength part of the spectrum,

$$
\ln \left[\frac{p(s)^{1 / 2}}{/ s /}\right]=\ln \mathrm{A}-2 \pi / \mathrm{s} / \mathrm{Z}_{\mathrm{o}}
$$

Where $\mathrm{P}(\mathrm{s})$ is the radially averaged power spectrum of the anomaly, $/ \mathrm{s} /$ is the wave number, and $\mathrm{A}$ is a constant.

The second step is the estimation of the depth to the top 
boundary $\left(Z_{t}\right)$ of that distribution from the slope of the second longest wavelength spectral segment (Okubo et al 1985),

$$
\ln \left[P(s)^{1 / 2}\right]=\ln \mathrm{B}-2 \pi / \mathrm{s} / \mathrm{Z}_{\mathrm{t}}
$$

Where $\mathrm{B}$, is the sum of constants independent of $/ \mathrm{s} /$.

Then the basal depth $\left(Z_{b}\right)$ of the magnetic source was calculated from the equation below,

$$
Z_{\mathrm{b}}=2 \mathrm{Z}_{\mathrm{o}}-\mathrm{Z}_{\mathrm{t}}
$$

The obtained basal depth $\left(Z_{b}\right)$ of a magnetic source is assumed to be the Curie point depth $[1,23]$. In computing the depth to Curie point, the magnetic residual data obtained from polynomial fitting of the Oasis Montaj software was divided into sixteen spectral blocks allowing spectral probe of $55 \mathrm{~km}$ by $55 \mathrm{~km}$ area for 30 minute by 30 minute windowing in order to accommodate longer wavelength so that depth of about $55 \mathrm{~km}$ could be investigated. A program written in matlab was used to obtain graphs of the logarithms of the spectral energies for the various blocks, the Curie point depth obtained from the graph is summarized in Table 1. Curie depth isotherm contour map was plotted alongside isometric projection (figures 4 and 5), which clearly show the nature of the curie depth in the study area. To confirm the curie depth in the area, the data of each block was continued upward to eliminate shallow sources and enhance the deep seated magnetic sources, for every single run of the program corresponding to a particular height $(+Z)$, it was necessary to carry out spectral analysis to see whether the criteria for removing the short and medium wavelengths were met. This was realized when the spectral show no ordering or quasihorizontal (scattered points) line for the unwanted components. In view of this, three profiles were drawn on the Curie Isotherm map (figure 4) to observe any relationship with topographic map of the area as shown on the 2-D models (figures 6-8).

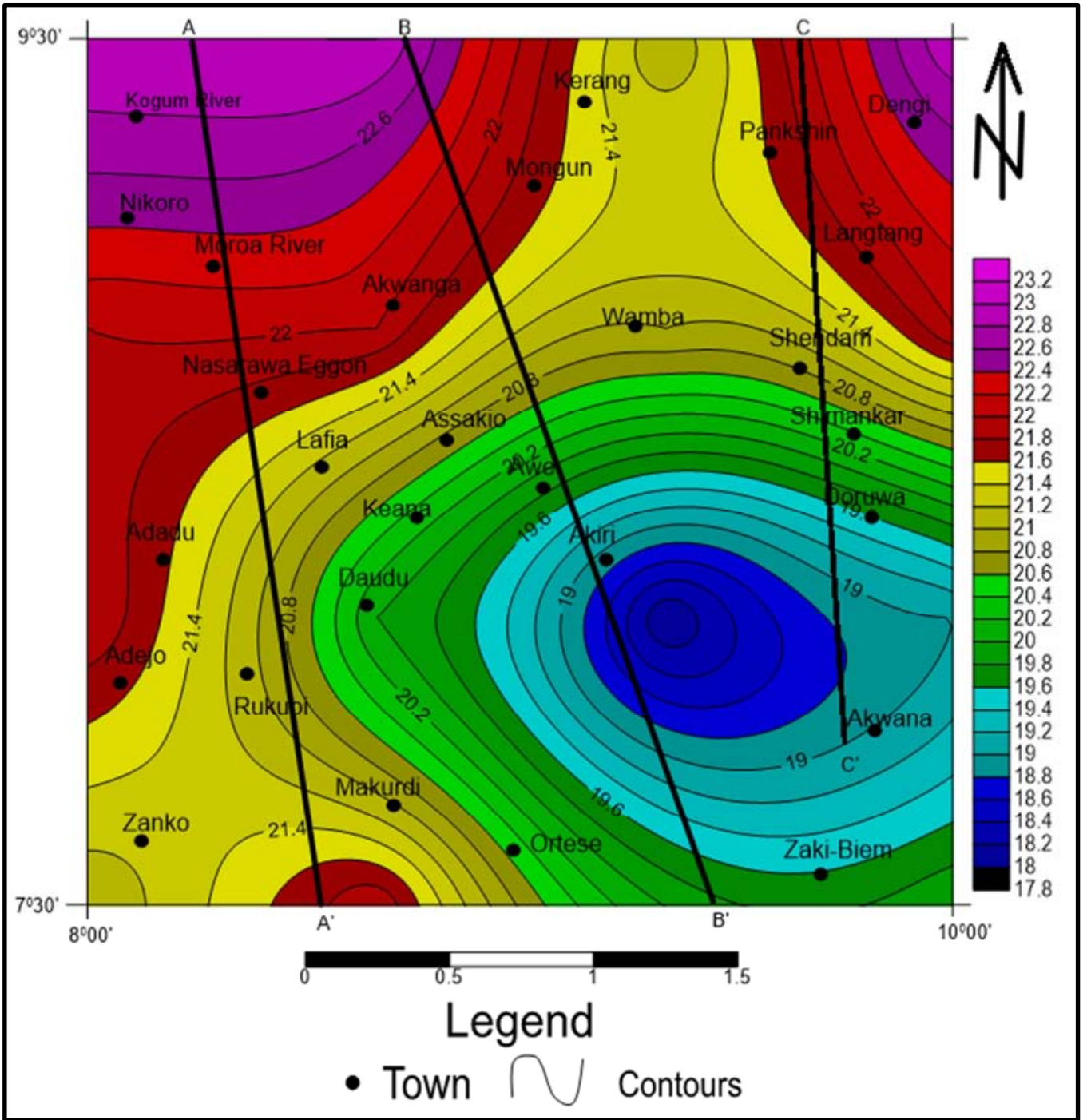

Figure 4. Curie Isotherm Map of the Study Area (Contour interval 0.2km). 


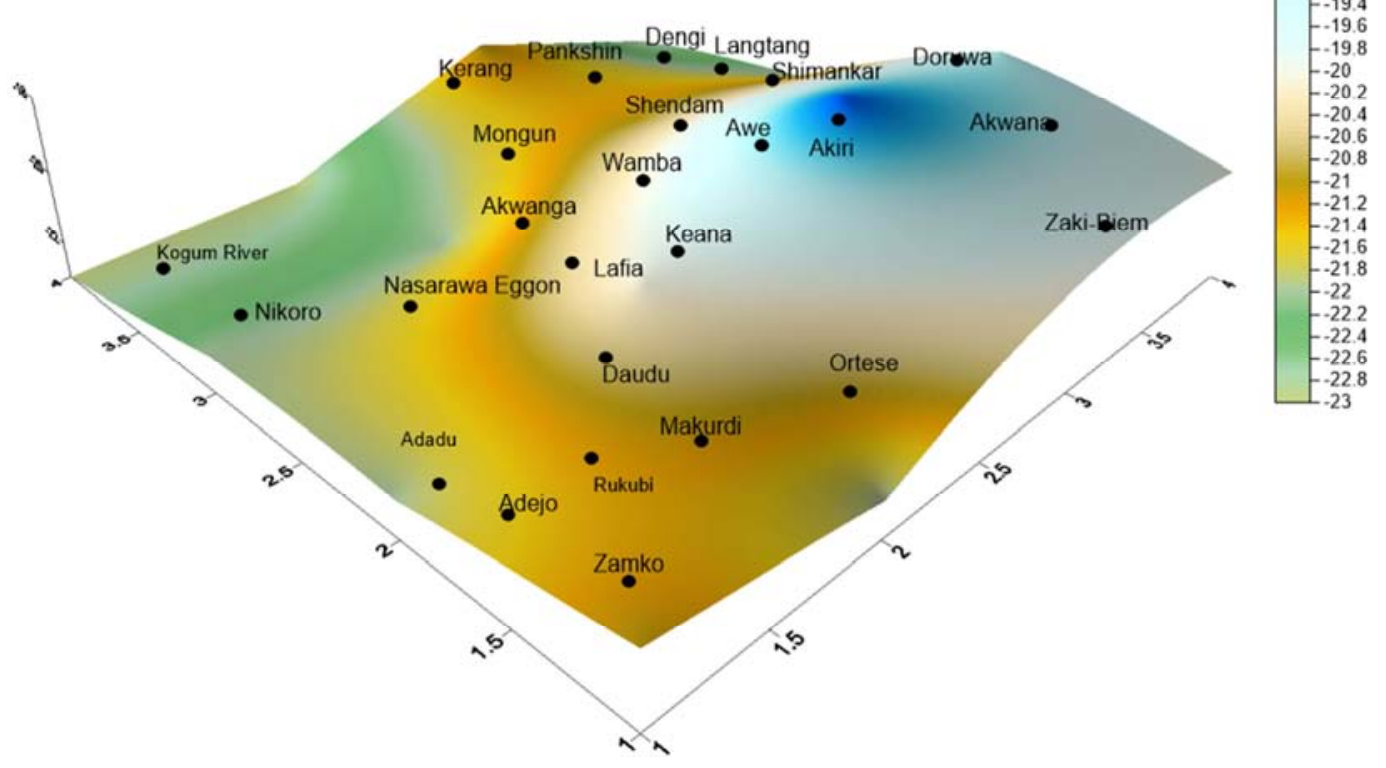

Figure 5. Isometric projection of Curie depth Isotherm of the Study Area.

Table 1. The Calculated Average Curie Point Depth (Isotherm) of the Study Area.

\begin{tabular}{llll}
\hline Block 13 & Block 14 & Block 15 & Block 16 \\
$\mathrm{Zo}=12.28$ & $\mathrm{Zo}=13.38$ & $\mathrm{Zo}=13.21$ & $\mathrm{Zo}=12.56$ \\
$\mathrm{Zt}=1.45$ & $\mathrm{Zt}=3.32$ & $\mathrm{Zt}=3.11$ & $\mathrm{Zt}=1.89$ \\
$\mathrm{Zb}=23$ & $\mathrm{Zb}=23$ & $\mathrm{Zb}=21$ & $\mathrm{Zb}=23$ \\
$\mathrm{Block} 9$ & $\mathrm{Block} 10$ & $\mathrm{Block} 11$ & $\mathrm{Block} 12$ \\
$\mathrm{Zo}=12.25$ & $\mathrm{Zo}=13.32$ & $\mathrm{Zo}=12.02$ & $\mathrm{Zo}=13.10$ \\
$\mathrm{Zt}=2.65$ & $\mathrm{Zt}=4.32$ & $\mathrm{Zt}=3.09$ & $\mathrm{Zt}=4.01$ \\
$\mathrm{Zb}=22$ & $\mathrm{Zb}=22$ & $\mathrm{Zb}=21$ & $\mathrm{Zb}=22$ \\
$\mathrm{Block} 5$ & $\mathrm{Block} 6$ & $\mathrm{Block} 7$ & $\mathrm{Block} 8$ \\
$\mathrm{Zo}=13.29$ & $\mathrm{Zo}=11.92$ & $\mathrm{Zo}=10.55$ & $\mathrm{Zo}=11.22$ \\
$\mathrm{Zt}=4.25$ & $\mathrm{Zt}=2.65$ & $\mathrm{Zt}=2.95$ & $\mathrm{Zt}=3.24$ \\
$\mathrm{Zb}=22$ & $\mathrm{Zb}=20$ & $\mathrm{Zb}=18$ & $\mathrm{Zb}=19$ \\
$\mathrm{Block} 1$ & $\mathrm{Block} 2$ & $\mathrm{Block} 3$ & $\mathrm{Block} 4$ \\
$\mathrm{Zo}=13.01$ & $\mathrm{Zo}=11.86$ & $\mathrm{Zo}=11.04$ & $\mathrm{Zo}=12.45$ \\
$\mathrm{Zt}=4.98$ & $\mathrm{Zt}=1.85$ & $\mathrm{Zt}=1.98$ & $\mathrm{Zt}=4.89$ \\
$\mathrm{Zb}=21$ & $\mathrm{Zb}=22$ & $\mathrm{Zb}=20$ & $\mathrm{Zb}=20$ \\
\hline
\end{tabular}

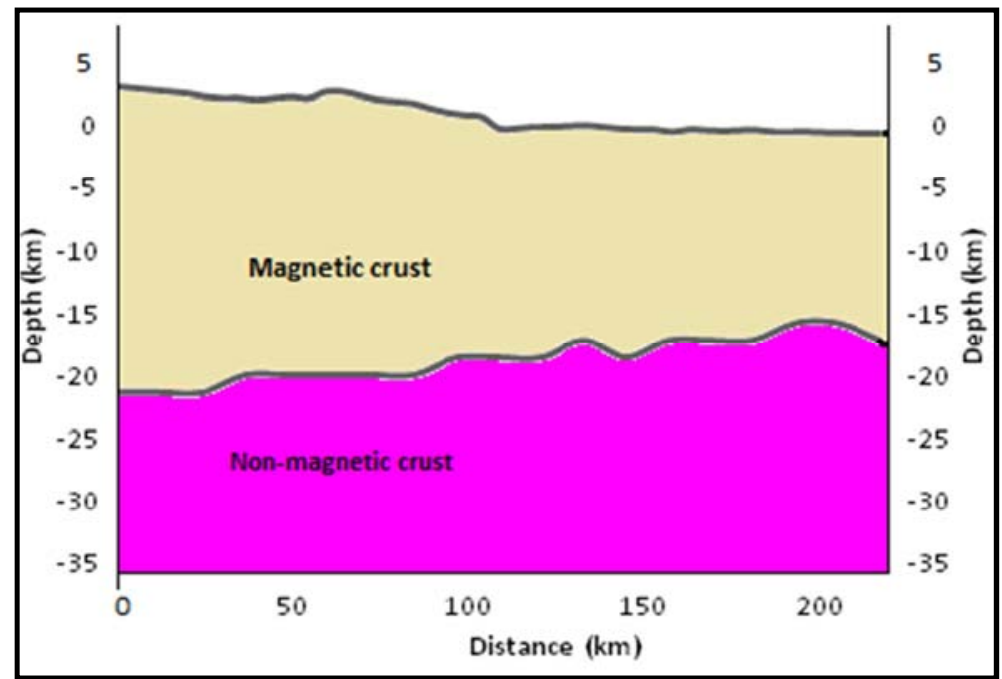

Figure 6. 2-D Curie depth model of profile $A-A^{\prime}$. 


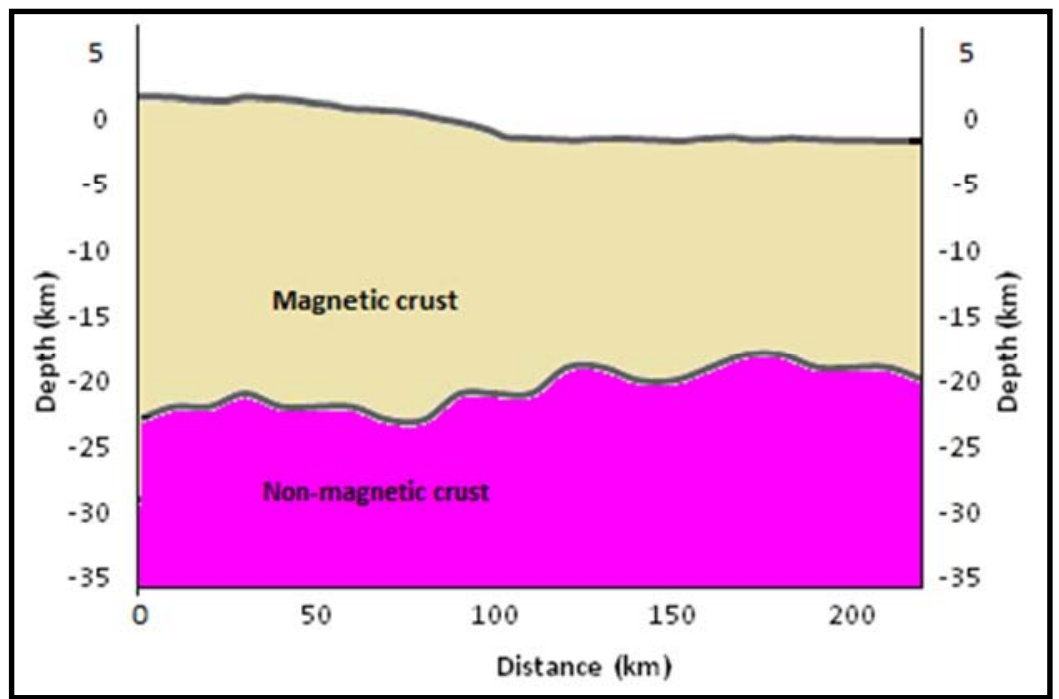

Figure 7. 2-D Curie depth model of profile B-B'.

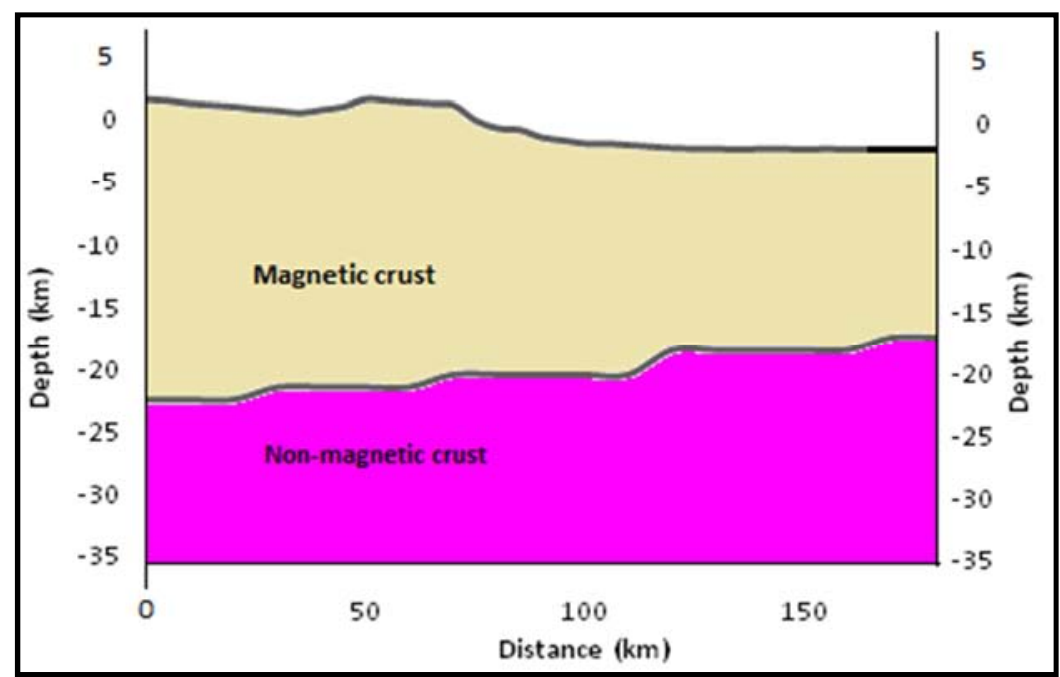

Figure 8. 2-D Curie depth model of profile $C$ - $C^{\prime}$.

\section{Estimation of Heat Flow and Thermal Gradient}

The heat flow and thermal gradient values was calculated to determine the thermal history of the crust in the study area. The calculation is expressed by Fourier's law with the following formula

$$
\mathrm{q}=\lambda \frac{\mathrm{dT}}{\mathrm{dZ}}
$$

Where $q$ is the heat flow and $\lambda$ is the coefficient of thermal conductivity. In this equation, it is assumed that the direction of the temperature variation is vertical and the temperature gradient $\mathrm{d}_{\mathrm{T}} / \mathrm{d}_{\mathrm{Z}}$ is constant. According to [31], the Curie temperature $(\theta)$ was obtained from the Curie point depth $\left(Z_{b}\right)$ and the thermal gradient $\mathrm{dT} / \mathrm{dZ}$ using the following equation;

$$
\theta=\left[\frac{\mathrm{dT}}{\mathrm{dZ}}\right] \mathrm{Z}_{\mathrm{b}}
$$

In this equation according to [31], it is assumed that the surface temperature is $0^{\circ} \mathrm{C}$ and no heat sources exist between the Earth's surface and the Curie point depth. In addition to that, from Equation (4) and Equation (5) a relationship can be determined between the Curie point depth $\left(Z_{b}\right)$ and the heat flow $(q)$ as follows.

$$
q=\lambda\left[\frac{\theta}{Z_{b}}\right]
$$

In this equation the Curie point depth is inversely proportional to the heat flow [29, 31], the Curie point temperature of $580^{\circ} \mathrm{C}$ was used (i.e. Curie temperature of magnetite), in order to compute the thermal gradient of the region. Thus, the thermal gradient was calculated from Curie temperature of magnetite $\left(580^{\circ} \mathrm{C}\right) / \mathrm{Curier}$ depth isotherm 
value $\left({ }^{\circ} \mathrm{C} / \mathrm{km}\right)$.

However, using an average thermal conductivity, $\lambda$ value of $2.5 \mathrm{Wm}^{-1}{ }^{\circ} \mathrm{C}^{1}[19,31]$ we have calculated the value for geothermal gradient in the study area using the empirical relation between curie depth, temperature and geothermal gradient (equation 6). The result is summarized in Table 2. The results were used to plot the heat flow contour map and is presented alongside isometric projection figures (9\& 10). These give the nature of heat distribution in the subsurface of the study area.

Table 2. Calculated Heat flow and Geothermal Gradient from Curie depths.

\begin{tabular}{|c|c|c|c|c|c|}
\hline Blocks & $\begin{array}{l}\text { Depth to Centroid }\left(\mathrm{Z}_{\mathrm{o}}\right) \\
\text { km }\end{array}$ & $\begin{array}{l}\text { Depth to Top bound }\left(Z_{t}\right) \\
\text { km }\end{array}$ & $\begin{array}{l}\text { Depth to Curie point } \\
\left(\mathrm{Z}_{b}\right) \mathbf{k m}\end{array}$ & Heat flow $\left(\mathrm{mWm}^{-2}\right)$ & $\begin{array}{l}\text { Geothermal gradient } \\
\left({ }^{\circ} \mathbf{C k m}^{-1}\right)\end{array}$ \\
\hline 1. & 13.01 & 4.98 & 21 & 70 & 28 \\
\hline 2. & 11.86 & 1.85 & 22 & 65 & 26 \\
\hline 3. & 11.04 & 1.98 & 20 & 73 & 29 \\
\hline 4. & 12.45 & 4.89 & 20 & 73 & 29 \\
\hline 5. & 13.29 & 4.25 & 22 & 65 & 26 \\
\hline 6. & 11.92 & 2.65 & 20 & 73 & 29 \\
\hline 7. & 10.55 & 2.95 & 18 & 80 & 32 \\
\hline 8. & 11.22 & 3.24 & 19 & 78 & 31 \\
\hline 9. & 12.25 & 2.65 & 22 & 65 & 26 \\
\hline 10 & 13.32 & 4.32 & 22 & 65 & 26 \\
\hline 11. & 12.02 & 3.09 & 21 & 70 & 28 \\
\hline 12. & 13.10 & 4.01 & 22 & 65 & 26 \\
\hline 13. & 12.28 & 1.45 & 23 & 63 & 25 \\
\hline 14. & 13.38 & 3.32 & 23 & 63 & 25 \\
\hline 15. & 13.21 & 3.11 & 21 & 70 & 28 \\
\hline 16. & 12.56 & 1.89 & 23 & 63 & 25 \\
\hline
\end{tabular}

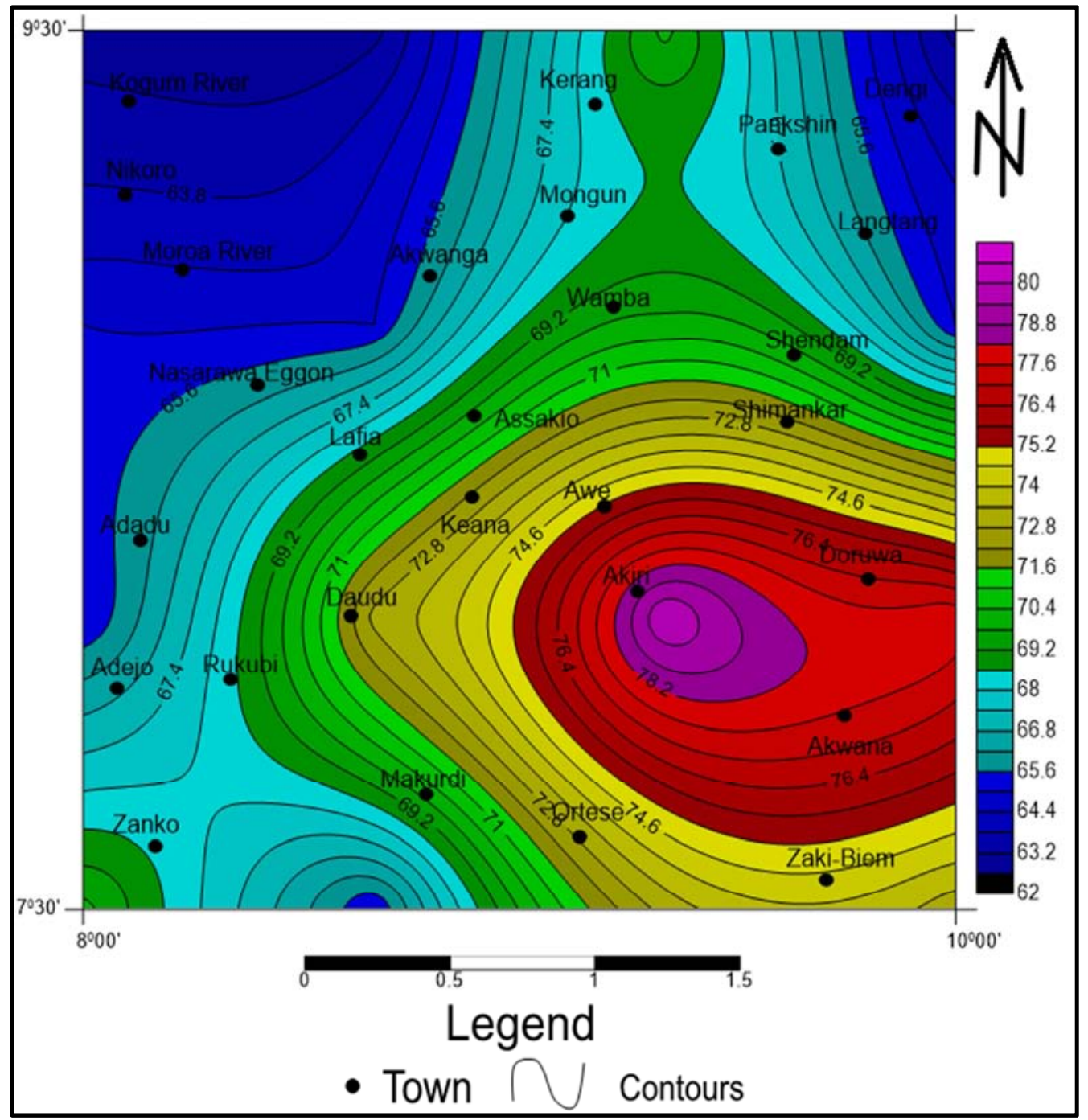

Figure 9. Heat Flow contour Map of the Study Area (Contour interval $0.2 \mathrm{Wm}^{-1} \mathrm{C}^{-1}$ ). 


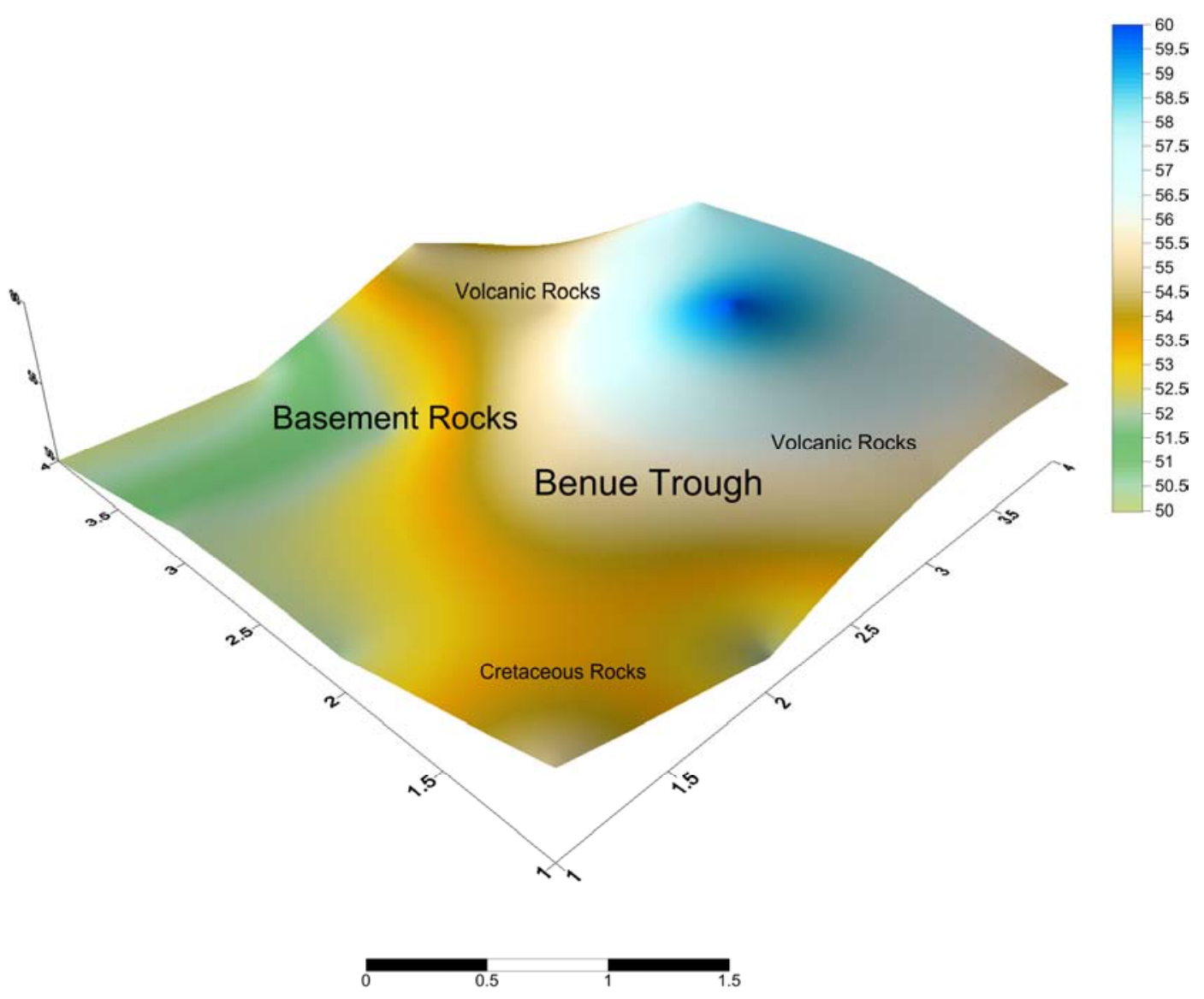

Figure 10. Isometric projection of Heat Flow of the Study Area.

Also, the inferred Curie point depth was plotted against heat flow, the graph shows an inverse relation between heat flow and Curie depths (figure 11).

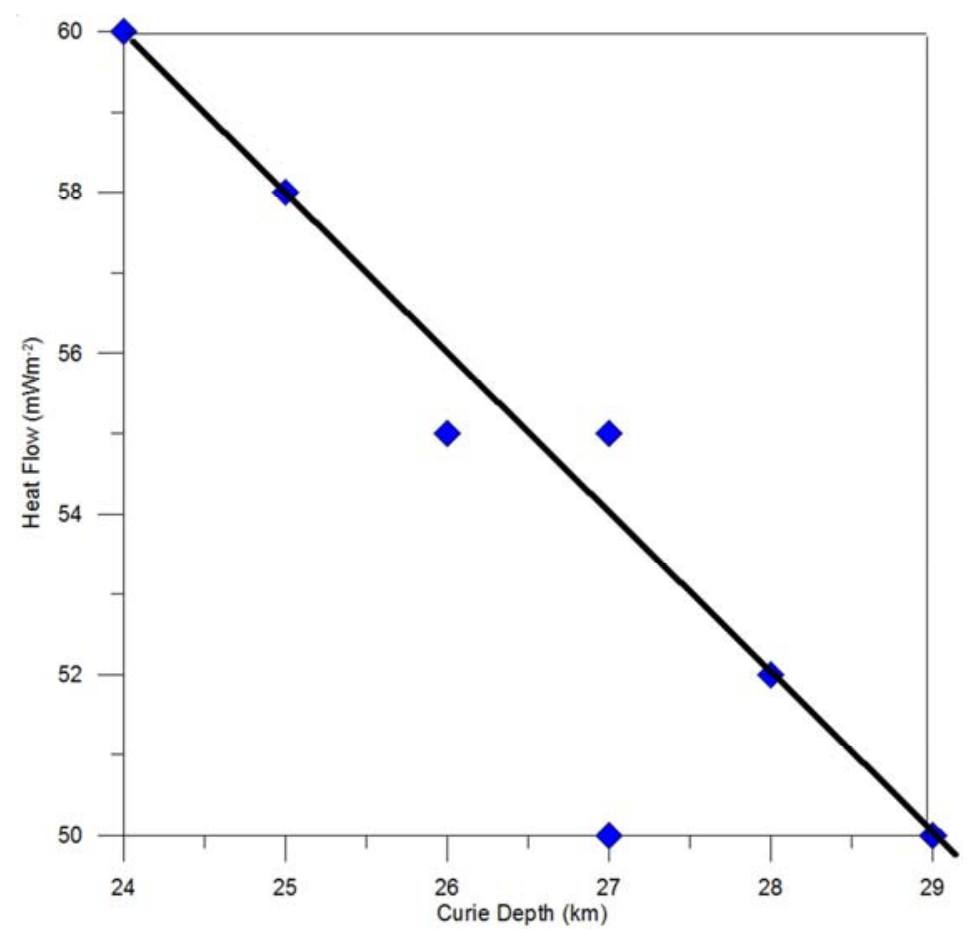

Figure 11. Heat Flow versus Curie depth in the Study Area.

The results of geothermal gradient obtained were also used to plot the geothermal contour map and presented alongside 
isometric projection in figures $(12, \& 13)$. These give the thermal history of the crust in the study area.

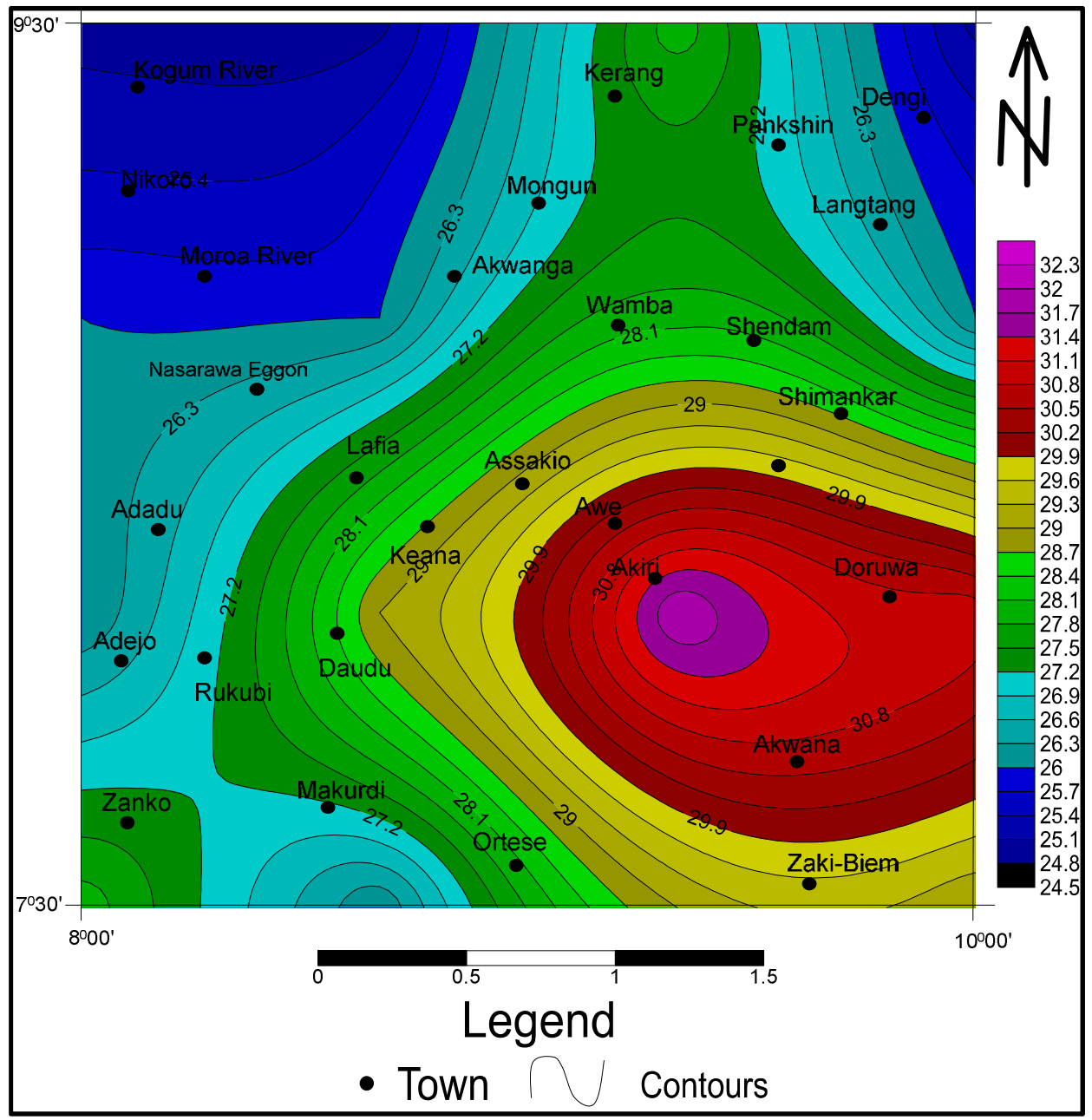

Figure 12. Geothermal Gradient contour Map of the Study Area (Contour interval $0.2^{\circ} \mathrm{C} / \mathrm{km}$ ).

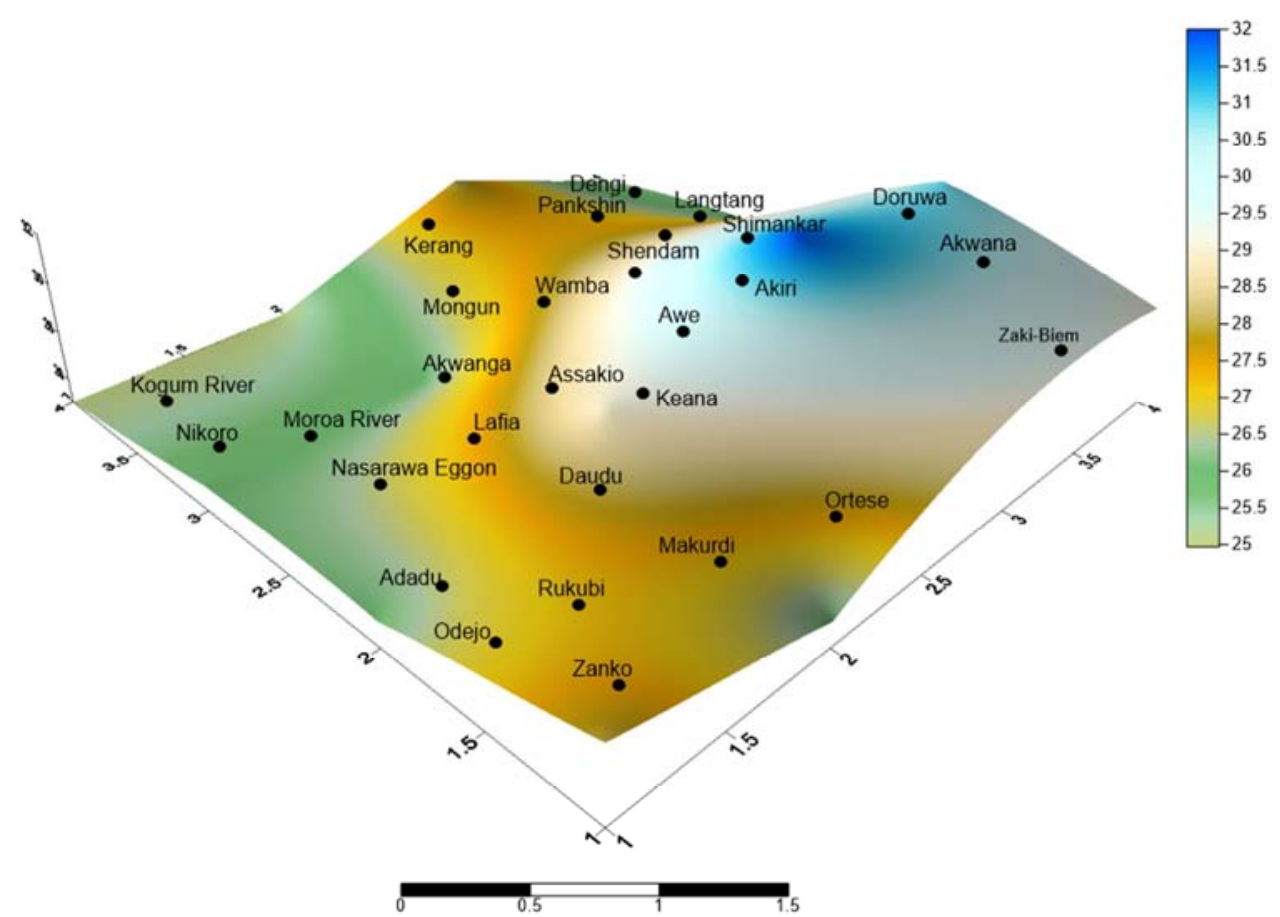

Figure 13. Isometric projection of Geothermal Gradient of the Study Area. 


\section{Discussion of the Results}

The computed Curie depth, heat flow and geothermal gradient of the study area using empirical formular based on a minimum ratio of 12:1 of block size to prism are discussed as follows; the depth to centroid $\left(Z_{0}\right)$ ranges from 10.55 to $13.38 \mathrm{~km}$, while the depth to the top boundary $\left(Z_{t}\right)$ of magnetic sources ranges from 1.45 to $4.98 \mathrm{~km}$. The equivalent curie depth ranges from 18 to $23 \mathrm{~km}$, these values compared well with what was obtained in some part of the Benue Trough, by $[16,19,22]$.

The obtained Curie point depths reflect the average local Curie point depth values beneath each block, the result shows that the curie isotherm surface is undulating, and variations of curie depth Isotherm could be related to the different tectonic activities. It is on these bases several ideas have been advanced to explain the origin and evolution of the Benue Trough. $[6,21]$ are of the view that the evolution of the Benue Trough involved astenospheric up doming, crustal thinning and stretching, emplacement of igneous bodies and block faulting, [25] interpreted regional gravity anomaly profiles in terms of an uparching of the mantle - crust interface, his model gives the crustal thickness in the Upper Benue Trough between 25 and $28 \mathrm{~km}$. [3], reported that the general configuration of the crust beneath the Benue Trough shows a thinning in the axis of the Trough. It was also observed that, areas of volcanic rocks on the geologic map (Figure 1) have moderate Curie point depth of $26 \mathrm{~km}$ compared to the crystalline basement area. This could be as a result of upwelling of magma during the Tertiary period, this means that, since volcanic activities are recent, heat flow in these areas can be higher due to cooling of the magma and these account for shallower curie depth. The deep Curie point at the north-western part of the study area could be as a result of thick crust under the crystalline basement, which implies that isostatic compensation might perhaps pushed the base of magnetic crust down to compensate the weight of the crystalline basement as shown on the curie depth models (Figure 6 - 8). A plot of Curie point depth versus heat flow values showed an inverse linear relationship (Figure 11), which implies that, heat flow increases with decrease in Curie point depth and vice versa. This indicates that all areas with shallow Curie depth are expected to have high heat flow.

The calculated heat flow and geothermal gradient obtained using an empirical method as summarized in table 2 gave the average heat flow as $69 \mathrm{mWm}^{-2}$; this may be considered as typical of continental crust [36]. In most part of the study area, heat flows is found to be less than 80 $\mathrm{mWm}^{-2}$, except for block seven (7), which has up to $80 \mathrm{mWm}^{-2}$, this is consistent with the values of Curie point depth noted in this area. The heat flow values show a general trend of decrease from the north-western part toward the south-eastern part. All areas having considerable heat flow correspond to areas of shallow curie depth and can be related to Benue rift and volcanic centres. The quantitative change in Curie depth (Figure 4) implies that, the heat flow in the study area is also not uniform. This is shown on the heat flow contour map (Figure 9) and its isometric projection (Figure 10).

The calculated geothermal gradient in the study area varied between 25 and $32^{\circ} \mathrm{Ckm}^{-1}$ with an average of $27^{\circ} \mathrm{Ckm}^{-1}$ as in Table 2. The assessment of variations of the Curie isotherm of an area can provide valuable information about the regional temperature distribution at depth and the concentration of subsurface geothermal energy [33]. One of the important parameter that determines the relative depth of the Curie isotherm with respect to sea level is the local thermal gradient. I.e. heat flow [11]. Measurements have shown that a region with significant geothermal energy is characterized by an anomalous high temperature gradient and heat flow $[13,33]$. It is therefore expected that geothermically active areas would be associated with shallow Curie point depth [17]. This relationship is demonstrated by the geothermal contour map (Figure 4) and their isometric projection (Figure 5), which indicates that areas with significant heat flow have high geothermal energy potentials. It is also known that the temperature inside the earth directly controls most of the geodynamic processes that are visible on the surface [19]. In line with this Heat flow measurements in several parts of African continent have revealed that the mechanical structure of the African lithosphere is variable [16].

This study has revealed that the south-eastern part of the study area is rich in geothermal energy especially areas around Akiri and environs because it is associated with shallow Curie point, high heat flow and high geothermal gradients. Records have shown that the Italians were the first to use geothermal energy to power gas turbines and California in the U.S.A is the largest user of geothermal energy, today many people around the world use geothermal energy for heating, and electricity generation. There is no doubt, the geothermal reservoir around Akiri area can be used for the same purposes, most especially nowadays that electricity supply is a major challenge, due to low capacity generation and high maintenance cost. This opportunity if properly harness is free, renewable, simple, pollution free because there is no emission, clean, safe with little harm to the environment and low operating cost, hence government can save a lot of money, the steam eliminates the need to transport, store and burn fossil fuels to run the turbines.

The situation at Akiri Hot Spring is a peculiar one, with surface temperature of about $56^{\circ} \mathrm{C}$ there is no doubt that Akiri Hot Spring area is rich in geothermal energy. [35] reported an average temperature gradient of $1^{\circ} \mathrm{C}$ for $30 \mathrm{~m}$ or $35^{\circ} \mathrm{C}$ per km obtainable in the lower Benue Trough, if that is applicable then the minimum depth of borehole required to achieve the threshold temperature of $115^{\circ} \mathrm{C}-180^{\circ} \mathrm{C}$ for the abstraction of geothermal energy in Akiri area would be $2.3 \mathrm{~km}$ deep. 


\section{Conclusion}

An assessment of the geothermal energy resources over parts of Nasarawa and environs was carried out using high resolution aeromagnetic data and the result shows that the southeastern part of the study area has high prospect, because it is associated with shallow Curie point, high heat flow and high geothermal gradient. It is now envisaged that if $2.3 \mathrm{~km}$ borehole is drilled, there is the possibility of achieving the threshold temperature of $115^{\circ} \mathrm{C}-180^{\circ} \mathrm{C}$ for the abstraction of geothermal energy in Akiri area. The application of the geothermal energy in developing such area as the generation of electric power, can be a major achievement for Nasarawa State Government and Nigeria at large. It is believed that the results obtained in this work have provided important geophysical/geological inputs which are useful to further geothermal energy exploration in the region.

\section{Acknowledgements}

The First author wishes to thank Geosoft Inc. South Africa for providing the software which I used for my $\mathrm{Ph}$. D. Research work. Thanks are also due to the department of Geology, Modibbo Adama University of Technology, Yola for the practical application of this work.

\section{References}

[1] Bhattacharryya, B. K. and L. K. Leu. (1975). Spectral Analysis of Gravity and Magnetic Anomalies due to Dimensional Structures, Geophysics, Vol. 40, pp. 993-1031.

[2] Bhattachryya, B. K. (1996). Continuous spectrum of the total magnetic field anomaly due to a rectangular prismatic body. Geophysics Vol. 31; 97-121.

[3] Benkhelil, J. (1989): The Origin and evolution of the Cretaceous Benue Trough, Nigeria. Jo urnal of 4/rican Earth Sciences 8, 251-282.

[4] Byerly, P. E. and Stolt, R. H. (1977). An attempt to define the Curie Point Isotherm in Northern and Central Arizona, Geophysics, Vol. 42, pp. 1394-1400.

[5] Blakely, R. J. (1988). Curie temperature, Isotherm Analysis and Tectonic Implications of Aeromagnetic Data from Nevada. Journal of Geophysical Research-Solid Earth, Vol. 93, pp. 11817-11832.

[6] Burke KC, Dewey JF (1972) Orogeny in Africa. In: Dessauvagie TFJ, Whiteman AJ (eds), Africageology. University of Ibadan Press, Ibadan, pp 583-608.

[7] Connard, G., Couch, R. and Gempererie, M. (1983). Analysis of Aeromagnetic measurement from the Cascade Range in Central Oregon, Geophysics, Vol. 48, pp. 376-390.

[8] Dobrin, M., \& Savit, C. (1988). Introduction To Geophysical Prospecting (Fourth Edition ed.). Singapore: McGraw-Hill.

[9] Dolmaz, M. N., Z. M. Hisarli., T. Ustaomer, and Orbay, N. (2005). Curie Points Depths based on Spectrum Analysis of the Aeromagnetic Data, West Anatolian Extensional Province, Turkey, Pure and Appl. Geol, Vol. 162, pp. 571-590.
[10] Ford, S. O. (1981): The Economic Mineral Resources of the Benue Trough. Earth Evolution Sciences Vol. 1, No. 2, pp154163.

[11] Hisarli, ZM (1996). Determination of Curie Point Depths in Western Anatolia and Related with the Geothermal Areas, Ph. D. Thesis, Istanbul University, Turkey (unpubl.), (in Turkish with English abstract).

[12] Johnson, W. W. (1969). A least - Squares method of interpreting magnetic anomalies caused by Two- Dimensional structures. Geophysics, Vol. 34, pp65 -74.

[13] Kasidi, S. and Nur, A. (2012) Curier isotherm deduced from spectral analysis over Sarti and environs north eastern Nigeria. Scholarly Journals of Biotechnology. Vol. 1 (3): 49-56.

[14] Nigerian Geological Survey Agency Abuja, 2006. Geological map of Nigeria, scale: 1:2,000,000.

[15] Nigerian Geological Survey Agency Abuja. 2009. High Resolution HRAM Airborne Geophysical Series Survey Grid Map of Total Intensity (16 sheets). Scale 1: 100,000.

[16] Nur, A., Ofeogbu, C. O. and Onuoha, K. M. (1999). Estimation of the depth to the courier point isotherm in the upper Benue trough, Nigeria. Jour. Min. Geol. 35 (1): 53-60.

[17] Nuri, DM, Timur, UZ, Mumtaz, H, Naci, O (2005). Curie Point Depth variations to infer thermal structure of the crust at the African-Eurasian convergence zone, SW Turkey. J. Earth planets Space. 57:373-383.

[18] Mishra, D. C. and Naidu, P. S; 1974. Two-dimentional Power spectral analysis of aeromagnetic fields, Geophysics Prop, 22, $345-534$.

[19] Nwankwo, L. I., Olasehinde, P. I. and Akoshile, C. O. (2011). Heat flow anomalies from spectral analysis of aeromagnetic data of Nupe Basin, Nigeria. Asian Journal of Earth Sciences. pages $1-7$.

[20] Offodile. M. E. (1976). The Geology of the Middle Benue, Nigeria. Palaentological Institute, University Uppsala, Special Publication,, 4:pp 1-166.

[21] Ofoegbu, C. O. (1984b). A model for the tectonic evolution of the Benue Trough of Nigeria. Geologische Rundschau, 73, 1007-1018.

[22] Ofoegbu, C. O. (1985). A review of the geology of the Benue Trough of the Nigeria; Journal of African Sciences, Vol. 3 pp. 285-291.

[23] Okubo, Y. J R. Graf, R. O. Hansen, K. Ogawa and H. Tsu. (1985). Curie point depth of the Island of Kyushu surrounding areas, Japan Geophysics. Vol. 53. pp. 481-491.

[24] Okubo, Y., H. Tsu, and K. Ogawa, (1989) Estimation of curie point temperature and geothermal structure of island arc of Japan, Tectonophysics, 159, 279-290.

[25] Osazuwa, I. B., Ajakaiye, D. E and Verheijn, P. J. T. (1981). Analysis of the structure part of the Benue Valley on the basis of new geophysical data Earth Evol. Sci. Vol. 2, pp. 126-135.

[26] Ross, H. E., Blakely, R. J. and. Zoback, M. D. (2006). Testing the use of aeromagnetic data for the determination of Curie depth in California. Geophysics, Volume 71, Pages 10-16. 
[27] Salem, A., Ushijima, K., Elsirafi, A., Mizunaga, H., 2000. Spectral analysis of aeromagnetic data for geothermal reconnaissance of Quesir area, northern Red Sea. Proceedings of the World Geothermal Congress 2000, International Geothermal Association/IGA, pp. 1669-1674.

[28] Skeels, D. C. (1967): What is Residual Gravity? Geophysics, 32: $872-876$

[29] Spector, A. and Grant, T. S. (1970). Statistical models for interpreting aeromagnetic data. Geophysics.

[30] Stampolidis, A. Kane, I. Tsokas G. N. and Tsourlo P., (2005). Curie point depths of Albania Inferred from Ground Total Field Magnetic Data. Surveys in Geophysics, Vol. 26, pp. 461480.

[31] Tanaka, A., Okubo, Y. and matsubayashi, O. (1999). Curie point depth based on spectrum analysis of the magnetic anomaly data in east and southeast Asia. Tectonophysics. Volume 306, pages 461-470.

[32] Trifonova, P., Zhelev, Zh., Petrova, T., Bojadgieva, K., (2006).
Curie point depths of Bulgarian territory inferred from geomagnetic observations and its correlation with regional thermal structure and seismicity. Tectonophysics 473, 362374.

[33] Tselentis, GA (1991). An attempt to define Curie depth in Greece from Aeromagnetic and heat flow data. PAGEOPH, $136(1): 87-101$

[34] Udensi, E. E., Osazuwa, I. B. and Daniyan, M. A. (2000). Production of a composite aeromagnetic map of the NupeBasin. Nigeria Journal of Science, Technology and Mathematics Education. Pages 150-159.

[35] Wright, J., Hastings, D., Jones, W., \& Williams, H. (1985). Geology and Mineral Resources of West Africa. London: George Allen and Unwin publishers Ltd.

[36] Yamano, M. (1995). Recent Heat Flow Studies in and around Japan. In: Gupta, M. L. and Yamano, M. (eds), Terrestrial Heat Flow and Geothermal Energy in Asia. A. A Balkema, Rotterdam, pp. 173-200. 